\title{
On the Construction of Core Curriculum System of Military Majors under the Condition of Field Combat
}

\author{
Yunpeng Xiao \\ Air Force Logistics University \\ Xuzhou, Jiangsu, 221000, China
}

\author{
Yuanli Zhao \\ Air Force Logistics University \\ Xuzhou, Jiangsu, 221000, China
}

\author{
Xi Chen \\ Air Force Logistics University \\ Xuzhou, Jiangsu, 221000, China
}

\begin{abstract}
That scientifically demonstrate the core curriculum construction is the guarantee for the core capabilities cultivation of military personnel in the new era. This paper sheds light on the current status of core curriculum system construction, analyzes the guiding ideology and basic principles of the construction of the core curriculum system of military majors, and on the basis of the post ability and quality requirements of military majors under the condition of actual combat, studies the measures of the construction of the core curriculum system, which provides theoretical support for the construction of the core curriculum system.
\end{abstract}

Keywords-real combat-oriented; military specialties; core curriculum; system

\section{INTRODUCTION}

President Xi has stated that the capabilities of fighting and winning are essential for a strong army. Chinese People's Liberation Army (PLA) and Chinese People's Armed Police Force should set the goal of winning the war; strengthen the combat training preparing for military battle, and practice innovative training mode under the condition of informatization. Train high-quality military personnel, further promote the combat training, gear school education for the troops, and solve the difficulties of the field combat training by addressing the need of field combat and strictly training troops. With the deepening of the reform of the PLA, the adjustment and reform of military academies have entered a new stage. The new demand for talents puts forward new requirements for the teaching of military academies. As the core curriculum is important to cultivate the core competence of the trainees, when compiling the new teaching syllabus, the construction of the core curriculum system is the key to the curriculum reform of military academies and an important guarantee to cultivate high-quality military talents.

\section{CURRENT STATUS OF CORE CURRICUlUM SYSTEM CONSTRUCTION}

In 1903s, the American has put forward the core curriculum based on the general education. Core curriculum system contains a series of basic courses, from which the undergraduates should choose as the compulsory courses. Through the core curriculum, the educators expected to enable students get the understanding of the framework of the world around them before them learning the professional courses. At that time, the core curriculum, together with the professional courses and the optional course constituted the undergraduate education curriculum system. It could cultivate students' personality comprehensively and broaden their basic knowledge [1]. As time goes by, the form and the connotation interpretation of the core curriculum are constantly changing. However, they are basically on the basis of the general education and highlighting the core curriculum necessary and compulsory for all students. The understanding of the core curriculum has already formed a framework, but it is still limited to the basic curriculum and has not developed to the construction of the core curriculum system [2].

Since the founding of the People's Republic of China, we have copied the education mode of the Soviet Union and applied it to the higher education to set specialties. The way that educates students according to the needs of the country is gradually exposing its vulnerability. As the general education of the western countries starts to get just recognition, the core curriculum begins take root in China [3]. At present, there are two interpretations of the curriculum in China. The one refers to the core curriculum concept raised by the western countries in general education. The other holds that it is the main course runs through the learning phases, or the few core courses [4]. The differences between the two can be translated into the distinctions between the general education and the specialized education. Comparing with the western education that emphasize students' knowledge foundation, Chinese higher education is still stuck in the tradition of giving priority to professional teaching rather than basic knowledge delivering. 
The core curriculum is hard to catch up with the professional one, let alone surpass it [5].

\section{THE BASIC IDEA OF CONSTRUCTING THE CORE CURRICULUM SYSTEM OF MILITARY SPECIALTY UNDER THE CONDITION OF FIELD COMBAT}

To construct the core curriculum system designed for actual combat, it is necessary to figure out what actual combat is. What are the requirements of actual combat teaching? The socalled actual combat teaching is to teach according to combat requirements in an environment similar to actual combat. In essence, it is to teach according to actual combat requirements and practice according to teaching. As for the military major, its talent cultivation is purpose-oriented. Modern war requires colleges and universities to cultivate military talents capable of winning local wars under the conditions of informationization, educate people for the battlefield, and enable graduates to get ready for fighting and winning as fast as possible. Then, it is necessary to take into account the comprehensive quality, military combat skills and professional ability for posts, to cultivate a military team with excellent basic quality, comprehensive quality and high development potential. The basic ideas should include the following three aspects.

\section{A. Understanding of general education, strengthen the comprehensive quality}

Military academy education, no matter it is diploma education, vocational education or job training, is based on education. Marx held that the purpose of education is to promote the all-round development of people. Whether social education or the education in military academy, the primary goal is to cultivate the comprehensive quality of students. Therefore, when constructing the curriculum system, military academy should take general education as the important part of the education, give full play to its role and set the core curriculum according to the subject of the training object.

\section{B. Strengthening military combat skills according to basic quality requirements in actual combat}

The training objects of military academies are the servicemen, the military personnel that meet the needs of military modernization and military battle. Therefore, all subjects, specialties in the military academy should design to train the military combat skills and morale demanded by the modern war. When establishing the curriculum system of military academies, we should set the standard of combat effectiveness, and determine the corresponding courses that meet the training requirements of military combat and in accordance with the overall requirements for training personnel capable of fighting and winning.

\section{Training the professional ability in line with the post ability demand}

The purpose of training in military academies is to supply talents for the modernization of the army and meet the demand of various posts in the army. Therefore, when establishing the core curriculum system, it is necessary to establish professional courses according to the training objectives and post capacity as well as the actual work of the army.

\section{THE BASIC PRINCIPLES OF CONSTRUCTING THE CORE CURRICULUM SYSTEM OF MILITARY SPECIALTY UNDER THE CONDITION OF ACTUAL COMBAT}

The core curriculum system construction must adhere to real combat, focus on battle effectiveness. It is necessary to establish a "war-oriented" teaching and learning concept, strengthen military property and the battle effectiveness standard, and launch teaching activities centering on winning the future war, to cultivate the students fighting capability and quality. Through analyzing the demand for the professional ability of students, considering from the general education, combat skills, and professional quality, there are 8 ability demands of students under the condition of the real combat, namely, professional basic ability, professional construction ability, professional management ability, professional analysis ability, information application ability, decision-making ability, professional development ability and commanding ability. Based on the 8 requirements, we can establish the capability structure of military professionals under the actual combat conditions. According to the training objectives and ability requirements, sort the current curriculum system to build the core curriculum system. While curriculum constructing, the following principles should be adhered to.

\section{A. Seting up the "people-oriented" core curriculum construction concept}

For diploma education, the core curriculum should focus on the curriculum design mode of general education. Based on the talent training concept of "laying a comprehensive foundation and forming a perfect personality”, add the service ability requirements of the training objects, including military quality and business ability. We should set up a correct talent cultivation concept and carry it out in every link of teaching. In terms of management, anyone, whether in the superior and subordinate level, should consult and discuss on an equal footing. In terms of teaching methods, the teaching is arranged according to students' cognitive rules and receptivity, and combines theory with practice. Create a favorable atmosphere for students, gradually set up the "people-oriented" concept. For the position training, focus on professional education curriculum design, cultivate students' professional ability while caring basic quality. The curriculum can be set according to the practice and actual combat forces work demand, matching the curriculum system and the ability structure system, in a bid to improve the training efficiency.

\section{B. Properly integrate general and professional courses to improve the development potential of students}

The core courses of military majors can be categorized into professional courses and general courses. The former is to cultivate the core competitiveness of students closely related to military professional jobs, while the task of the latter is to cultivate students' basic knowledge and humanistic spirit. As China has kept the professional education of the Soviet Union since the founding of the People's Republic of China, there is a way of thinking that puts professional courses and general 
education courses in opposition, which is not conducive to the optimization of curriculum resources. What's worse, it not only causes the waste of curriculum resources, but also increases students' academic burden. Given this, military colleges and universities should arrange general courses according to the professional characteristics of the students, and integrate the professional courses and general courses, so that the two can supplement each other in an organic multiplication relationship.

\section{Reasonably determine the content of the core curriculum based on actual combat}

The content of the core curriculum is the core teaching content. The core curriculum of military major should contain the knowledge and quality needed to cultivate the core ability of military talents at a certain level, and its content is influenced by many factors such as discipline and specialty and educational environment. Therefore, neither the content of core curriculum of western countries, nor the core curriculum of local colleges and universities can be copied. Military specialized core curriculum content should be designed to help students' master basic knowledge and basic skills needed for their development in the army. It should not be compiled from just one aspect of subject or profession, but take into account the objective requirement that students need to know the world, understand the world, so that they can take in more comprehensive knowledge functioning basically. In addition, the content of the core curriculum should be comprehensive, that is, avoid being limited to a certain discipline and study something the specialty does not have, including the applied knowledge and ability required for social development, so that students can develop in harmony with the society and contact the outside world. The content of core courses should have a certain profundity, so that students can learn the core content of a certain aspect, and consolidate their competence.

\section{Supporting MeAsures FOR THE CONSTRUCtion OF CORE CURRICULUM SYSTEM OF MILITARY SPECIALTY UNDER THE CONDITION OF FIELD COMBAT}

\section{A. Strengthening the field combat teaching concept}

Follow the instruction of the Central Military Commission to carry out training as the combat, and carry out university education for military forces. Based on the military professional quality required in combat, carry out the combat teaching seminars to guide the faculty to strengthen practical teaching concept. Teaching staff should bear in mind the fighting capacity, the only fundamental standard, strengthen the concept of war, highlight fighting capability, teach around fighting, and evaluate the teaching effects the combat effectiveness standard.

\section{B. Improving the structure of the teaching group and strive to enable them to get familiar with the army}

Teachers in colleges and universities are the basis of organizing and implementing practical combat teaching. A high-quality teaching team is fundamental to improving the quality of personnel training. In order to achieve good results in the construction of the core curriculum system of military majors, it is necessary to further improve the professional level of the teaching staff and improve the structure of educational background and professional title. We should improve the structure of academic relationships, center on the needs of professional teaching, and actively introduce professional talents from colleges and localities to supplement the teaching team, and retain graduates who have performed well in their own training to stay at the school and teach. Actively coordinate organs and troops, organize teachers to participate in exercises and drills, post training, acting training, research and study in a planned and targeted way, and go to the frontline troops to learn how to carry out field combat teaching, enrich their field combat experience. We should make full use of the teaching strength of the army and other colleges and universities, establish a mechanism by which military instructors and teachers from other colleges and universities give lectures regularly, and build a team of full-time teachers, instructors and visiting teachers, so as to improve the actual combat teaching level as a whole.

\section{Increasing funds input, constantly improve the teaching security}

Make more efforts to strengthen the laboratory automation and information construction, and improve the comprehensive ability of personnel. Combining with the needs of military majors, we can highlight the comprehensiveness and practicability of education, by building a comprehensive multiaircraft oil support personnel training base with complete functions and supporting facilities. Relying on the construction of the experimental center, the key investment can be made to strive to build an integrated teaching and scientific research experimental system with complete functions, facilities, distinctive features and guarantee, so as to meet the needs of training compound oil support talents and increasing the serving ability of students. At the same time, the construction and use of teaching simulation training facilities and equipment should be accelerated to give full play to the professional characteristics and advantages of the talent training base.

\section{Carrying out in-depth research on field combat and update the content of teaching materials}

Based on the requirements of military professional ability and quality, we can study the special requirements of practical teaching, and demonstrate how to improve teaching material of practical teaching. In combination with the arrangement of the exercises and drills, we can organize the instructors in batches to participate in large-scale activities and the actual work of the troops, so as to understand the actual combat training of the troops and collect first-hand data for the professional combat teaching. Visit other colleges and universities for investigation and learn from their advanced practice in the combat teaching reform. An expert group can set up to organize the above contents in a planned way, and to update and improve the professional core course textbooks on a regular basis according to the college's textbook construction plan, so as to ensure that the course teaching meets the requirements of the army in actual combat. 


\section{REFERENCES}

[1] Wang Shouheng, Zha Xiaohu. Pedagogy Tutorial [M]. Hefei: Anhui University Press, 2001.

[2] Dictionary of Education [M]. Shanghai: Shanghai Educational Publishing House, 1990-1992.
[3] Zhang Hua. Curriculum and Teaching Methodology [M]. Shanghai: Shanghai Educational Publishing House, 2000.

[4] Zhang Jihua. On College Curriculum Reform and Development Trend [J]. Meitan Higher Education, 2000 (3):36-38.

[5] Yang Renyu. College Curriculum Reform and Development Trend [J]. Higher Education of Sciences, 2003(2):16-18. 